\title{
August-November Seed and Litter Fall in a Mature White Spruce Stand ${ }^{1}$
}

\author{
By R. M. Waldron ${ }^{2}$
}

Between early August and late November 1961, a record was kept of the number of white spruce seeds and amount of litter collected in thirty-two $1 / 4$-milliacre traps set out on two 1/10-acre plots within a mature white spruce stand located on the Riding Mountain Forest Experimental Area in Manitoba. The stand contained a total basal area of 180 square feet per acre, 9 of which were trembling aspen.

During the period of observation, some 119 days, approximately $11 / 2$ million seeds ( 70 per cent sound by cutting tests) fell per acre. This is equivalent to 5.9 pounds of seed and was produced from a cone crop rated as moderate. During the same period a total of 1,890 pounds of air-dried litter fell per acre: 1,460 pounds of needles, 350 pounds $^{3}$ of aspen leaves, and 80 pounds of other materials - principally twigs.

The heaviest period of seed dispersal preceded the heaviest period of litter fall by over one month (Figure 1). By October 3rd, 70 per cent of the seed but only 20 per cent of the litter collected during the period had fallen. Aspen leaf fall did not commence until after 60 per cent of the seed had been dispersed. Similar trends in the periodicity of seed and litter fall were recorded during 1955 and 1962.

Early seed dispersal in relation to litter fall should have a significant effect on white spruce regeneration, particularly on scarified areas, since more seed would be likely to come in contact with favourable seedbeds than if they fell after the litter. The importance of getting seed on a bare mineral soil seedbed prior to litter fall was revealed by a greenhouse experiment conducted by Cayford and Waldron in $1961^{4}$. It was found that germination of white spruce seed on a clay soil was greater when seed was sown before rather than after a simulated needle or aspen leaf fall, and that one-eighth inch depth of needles or three thicknesses of leaves over seed did not prevent satisfactory germination in the greenhouse. The average four-month needle fall in this study was 1/32 inch deep and the leaf fall even less (total leaf area was only $50 \%$ of plot area). It may, therefore, be concluded that litter fall in this stand would not be detrimental to the germination of white spruce seed.

It is possible, however, that in stands containing a substantial aspen component, leaves flattened by a winter's snow, would be a limiting factor in spruce germination.

\footnotetext{
${ }^{1}$ Department of Forestry, Canada, Forest Research Branch Contribution No. 522.

2 Forest Research Officer, Dept. of Forestry, Manitoba-Saskatchewan District Office, Winnipeg, Manitoba.

"Cayford, J. H. and R. M. Waldron. 1962. Some effects of leaf and needle litter on greenhouse germination of white spruce and jack pine seed. For. Chron. 38: 229-231.

${ }^{3}$ Equivalent to slightly more than one million leaves.
} 


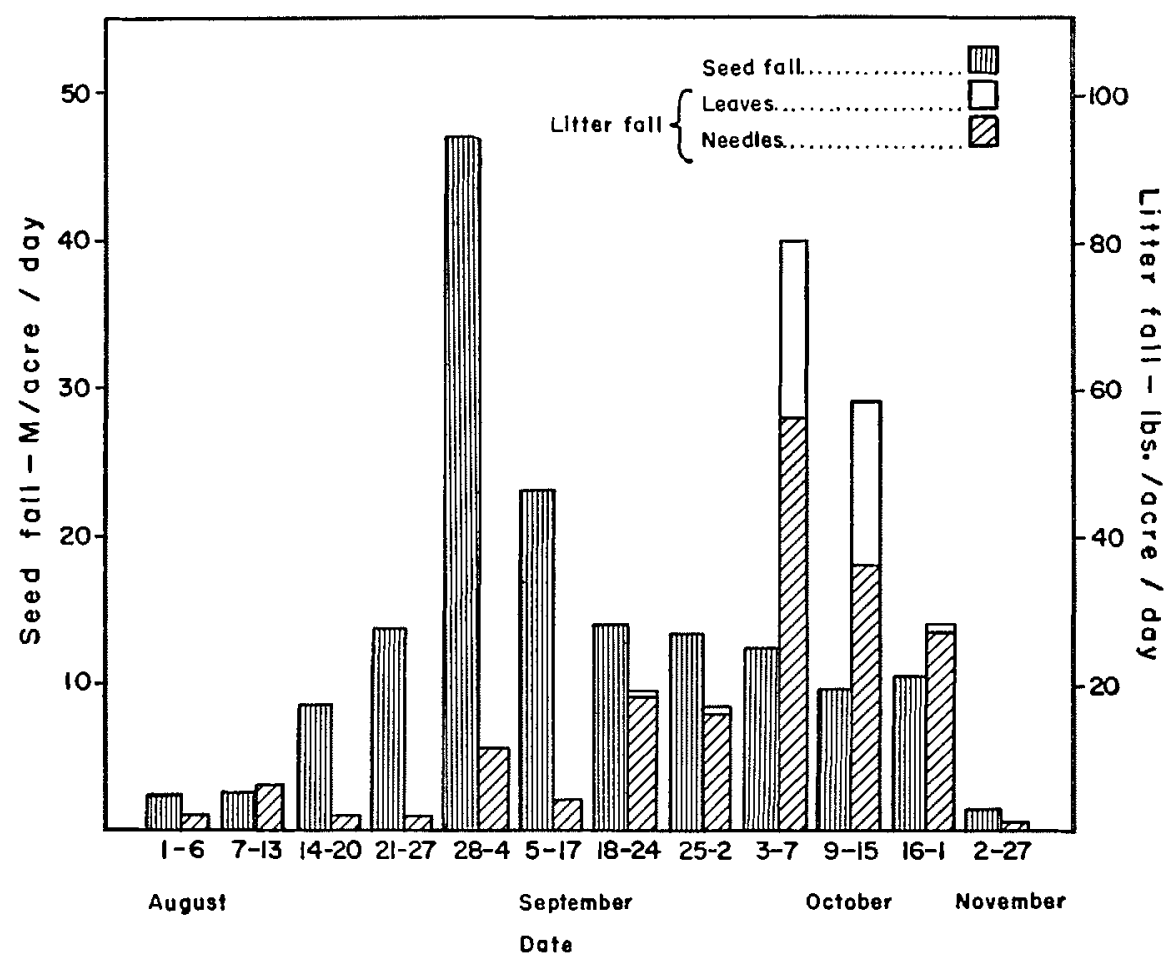

A Preliminary Study to Assess COMpetrTion in a White Spruce Trembling Aspen Stand

By G. A. Steneker and J. M. Jarvis ${ }^{2}$

This note presents the results of a preliminary investigation made in 1961 in a white spruce - trembling aspen ${ }^{3}$ stand near Reserve, Saskatchewan. The purpose of the investigation was to determine how the diameter increment of individual white spruce trees is influenced by the proximity of surrounding trees. Aspen ranged from 60 to 70 years in age, 40 to 70 feet in height and 4 to 12 inches in diameter; white spruce ranged from 40 to 70 years in age, 20 to 50 feet in height and 1 to 10 inches in diameter.

Although the study was limited in scope, the procedures used have shown promise and they may provide a lead for the development of mathematical formulae to express competition in such stands.

Thirty-eight white spruce trees, 4 to 10 inches in diameter, were selected for study. Their total height, breast-height diameter and 10-year (1951-1961) diameter increment (range: 0.5 to 3.5 inches) were determined. Diameter

${ }^{1}$ Contribution No. 509 from the Forest Research Branch, Department of Forestry.

${ }^{2}$ Research Officers, Dept. of Forestry, Forest Research Branch, Manitoba-Saskatchewan District Office, Winnipeg, Manitoba.

${ }^{3}$ Picea glauca (Moench) Voss, Populus tremuloides Michx. 